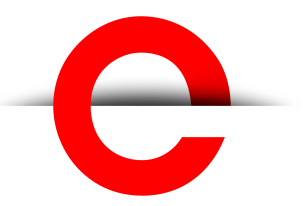

U T S

e PRES S
PORTAL Journal of Multidisciplinary International Studies

Vol. 17, No. $1 / 2$

Jan 2021

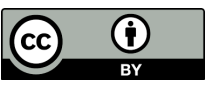

(c) 2021 by the author(s). This is an Open Access article distributed under the terms of the Creative Commons Attribution 4.0 International (CC BY 4.0) License (https:// creativecommons.org/ licenses/by/4.0/), allowing third parties to copy and redistribute the material in any medium or format and to remix, transform, and build upon the material for any purpose, even commercially, provided the original work is properly cited and states its license.

Citation: Manganas, N., and Loda, A. 2021. A Borrowed Life: Introduction to the Great Dis-Equalizer-the COVID-19 Crisis. PORTAL Journal of Multidisciplinary International Studies, 17:1/2, 1-6. http:// dx.doi.org/10.5130/pjmis. v17i1-2.7536

ISSN 1449-2490 | Published by UTS ePRESS | http://epress. lib.uts.edu.au/ojs/index.php/ portal
ESSAY

\section{A Borrowed Life: Introduction to the Great Dis-Equalizer-the COVID-19 Crisis}

\author{
Nicholas Manganas ${ }^{1}$ and Alice Loda ${ }^{2}$ \\ 1 University of Technology Sydney \\ ${ }^{2}$ University of Technology Sydney
}

Corresponding author: Nicholas Manganas, School of International Studies and Education, Faculty of Arts \& Social Sciences, University of Technology Sydney, 15 Broadway, Ultimo NSW 2007, Australia. Nicholas.ManganasQuts.edu.au

DOI: http://dx.doi.org/10.5130/pjmis.v17i1-2.7536

Article History: Published 28/01/2021

\begin{abstract}
Introduction to the curated issue of PORTAL Journal of Multidisciplinary International Studies, The Great Dis-Equalizer: The COVID-19 Crisis.
\end{abstract}

\section{Keywords}

COVID-19; Pandemic; New Normal; Crisis; Virus; Affect

We are all in this together.

We are all in the same boat.

This is the new normal.

The COVID-19 crisis — as much economic and political as biological and affective- is a shared global event that made present the fragility of the world we live in. The crisis was quickly heralded as the onset of a new normal, as media and political elites rushed to reassure us that the pandemic was the 'great equalizer' and that we all had to come together in solidarity to defeat the spread of the virus. The tendency to universalize the lived experience of the crisis and living in lockdown by asking people to adapt to the 'new normal' by appealing to their sense of vulnerability and affective bonds, only served to underscore that the pandemic did not, in fact, affect people equally. This special issue of PORTAL presents diverse accounts 
U T S

e PRES S of living in lockdown or through the pandemic in ways that significantly unsettle the narrative of the COVID-19 crisis as the 'great equalizer.'The collection hosts a series of self-reflective essays and cultural works that discuss the authors' individual experiences of the COVID-19 crisis in diverse contexts, including Australia, South and North America, Asia, Africa and Europe. The collection of first-hand narrative accounts aims to contribute to reframing the pandemic as the 'great dis-equalizer.'

We begin by reflecting on the virus itself. A virus is an infectious agent capable of multiplying exponentially in living cells. In biology, viruses occupy an uncanny transformative space between the living and the nonliving ( Villareal 2008). More android than living organism, its etymology can be traced to the Latin virus, a polysemantic word that includes 'poison' as one of its most attested meanings (Villareal 2008). Determining whether viruses are living organisms is complicated by the difficulty in defining life itself (Villareal 2008). While viruses display some of the characteristics of a life form, they do not exhibit many others. The survival of a virus depends on host cells, leading virologists van Regenmortel and Mahy to suggest that viruses lead 'a kind of borrowed life' (Villareal 2008; our emphasis). This is an apt metaphor because the COVID-19 virus has accentuated how our very existence is beginning to resemble a borrowed life in the sense that the act of borrowing is increasingly defining our everyday existence. We borrow money to survive (debt); we borrow our identities (appropriation); we borrow from other languages (loan words). Our lifestyles, too, increasingly borrow trouble; that is, our actions result in adverse reactions or repercussions, from climate change and environmental degradation to loneliness and precarity. To keep up with the neoliberal demand of always presenting the best version of ourselves we adorn ourselves with borrowed plumes, never too sure what is truly our own. A borrowed life has become, in many instances, all we know.

COVID-19 was an unflinching reminder that 'viruses matter to life' (Villareal 2008), that a borrowed life can overturn life itself. The Merriam-Webster dictionary defines a virus as 'something that poisons the mind or soul.' Indeed, alongside the viral infection that attacks our lungs, the pandemic assaulted our minds, also exposing the ideological viruses that had been circulating in our societies for a number of years: racism, fake news, conspiracy theories (Žižek 2020: 39). There is a growing sense-whether real or imagined-that civil society is being poisoned by the extreme polarization of the mediasphere. Social media either echoes our thoughts or makes us mad, as we scroll down in search of borrowed memes, unconsciously absorbing the decision of algorithms that decide for us what is of interest and what is not. The poisoning of the mind or soul filtered through the technologies we crave is intimately mirrored in yet another definition of a virus: 'a computer program that is usually disguised as an innocuous program or file, that often produces copies of itself [...] and that when run usually performs a malicious action' (Merriam-Webster 2020). The COVID-19 virus is similarly embodied in our hard drives; we put up our firewalls and await its malicious intent. It is curious that antiviral medications cannot kill a virus as it is difficult to kill something that is not quite alive. Instead, they can only hope to shut off a virus's replication process, inhibiting its development. The virus itself remains, planting its seed of doubt in our bodies and minds.

Viruses have been often described as apolitical, democratic, and not distinguishing between the rich and poor (Žižek 2020: 42). As COVID-19 spread rapidly in China and then the world, as country after country succumbed to its reach, there was a real sense that indeed we were all in the same boat, connected through our incapacity to fight it and perhaps in our hopes and fears. In many cases, we watched the same news, we spoke with our families and loved ones across oceans, shared stories of our treks to buy toilet paper. Zoom became, for many, a daily companion in both professional and personal lives. Old friends messaged to check-in, often after years of silence. Distance was experienced in unprecedented ways. The importance of those we care for and the value of our communities became extremely tangible in a moment when touching was restricted or impossible. A novel, unfamiliar, and radical solitude appears in many observations of life through the pandemic, including in this special issue. And yet, we also find in this collection an account of 
U T S

e PRES S

the many strategies that individuals and groups have put in place to manage these feelings, and the diversity of situations and personal responses that it is generating.

This special issue underlines that the idea of the pandemic as a universalising force needs to be deconstructed, complicated and challenged. Humans have an innate desire for shared experiences and community building. The tendency to universalize experiences is rooted in religion which seeks to propagate the universal applicability of one (or multiple) Gods and one truth. In philosophy, universality claims that universal facts exist and can be discovered. And indeed was it not a fact that the COVID-19 virus could infect anybody regardless of age, gender, ethnicity, sexual orientation and socioeconomic status? And was it not the case that lockdown and restrictions were imposed on all sections of society? However, calling COVID-19 the 'great equalizer' because it could infect us all equally reduced the pandemic to its biological essence, an absurdity when the lived reality of the lockdown and the pandemic was experienced so unequally as many of the articles in this special issue underscore.

In order to deconstruct the idea of the COVID-19 pandemic as 'the great equalizer' it is important to reflect on it in light of the critical notion of crisis. Crises are often hijacked by the state to justify a host of critical changes to society, including to workers' rights and conditions. As large portions of the world entered varying forms of lockdown, long-standing cleavages (both political and socioeconomic) that had been conveniently forgotten by neo-liberal regimes, once again reared their ugly head. The truism that during a crisis everyone is a socialist could not conceal the disparity between the propertied classes and the working poor, between secure and insecure work. In Australia, the second wave of the virus that hit Melbourne in July 2020, spurred a national conversation on the need for paid sick leave for insecure and precarious workers. What a few months before had been considered a privilege was now deemed a public health priority. The Government's 'socialist' largess also did not extend to all workers equally. Workers at Australian universities, for example, did not meet the criteria that the Government set for its JobKeeper program. By October 2020, nearly 12,500 workers had lost their jobs at Australian universities (around 10 per cent of the pre-pandemic workforce) (Zhou 2020). The medium- and long-term consequences for the sector remain to be seen.

In Italy, some medical professionals were forced to triage their treatment of patients, sorting and ordering patients based on who they deemed had a greater chance of survival (Horowitz 2020). Whereas triaging is standard practice when hospitals are overwhelmed, necropolitical discourses about which lives are expendable and which lives need to be protected, circulated in many troubling contexts. In a heart wrenching episode of $Q \mathcal{E} A$ on Australia's $\mathrm{ABC}$, human rights lawyer Rosemary Kayess, highlighted the inhumanity of such discourse when it is your own life that is determined to be expendable because of your disability: 'it was such a visceral reaction that I had [...] My life wasn't valued and I was dispensable [...] I was not one of the real people' (2020). Australia's ex-Prime Minister Tony Abbott railed against the 'health dictatorship' that seeks to prioritize the saving of lives over the health of the economy: 'In this climate of fear, it was hard for governments to ask "how much is a life worth?" because every life is precious, and every death is sad, but that has never stopped families sometimes electing to make elderly relatives as comfortable

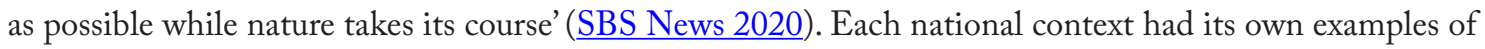
uncomfortable conversations that sought to grapple with who could potentially be left to die and whose life should be saved. Such conversations often took place alongside online and street protests by negationists (those who sought to deny the virus's existence or at least its deadly impact).

Lockdowns have been the most controversial aspect of the pandemic, pitting the scientific logic behind forced quarantine against the ideological imperative to curtail the various elements of a state of exception: surveillance, expanded executive powers, restrictions on movement. Italian philosopher Giorgio Agamben became the poster child for the ideological resistance against lockdowns by suggesting that epidemics have now replaced terrorism as the justification for exceptional measures (2020a). For Agamben, the new normal is the fact that we have become habituated to governments relying on the state of exception: 'States of 
collective panic,' he argues, 'are the perfect pretext for governments to limit freedoms in the name of safety' (2020a). His premise that 'society no longer believes in anything but bare life' leads him to question the worth of a society that values nothing other than survival (2020b). His argument is rather flimsy when you consider that many European countries, including Italy, lifted restrictions in the summer, opening up its national and regional borders, underestimating health advice in an attempt to stimulate the economy. The strategy worked but by September a second wave of the virus swept through Europe (and other parts of the world). Although this time national governments were not caught by surprise, the psychological toll was arguably worse as time seemed to stand even more still, testing people's patience for perhaps a moment too long.

Bruno Latour likewise questioned whether COVID-19 is a dress rehearsal for the impending climate change catastrophe. He suggests that war against the virus is unjustified and the health restrictions a caricature of Foucault's biopolitics:

pandemics awaken in leaders and those in power a kind of self-evident sense of "protection"- "we have to protect you" "you have to protect us" - that recharges the authority of the state and allows it to demand what would otherwise be met with riots. $(\underline{\mathbf{2 0 2 0}})$

For Latour, although the nation-state can readily perform biopolitics by mobilizing against a virus, it is ill-prepared to fight against the imminent ecological crisis (2020). Others like Jeffrey Frankel suggested that COVID-19 and the climate crisis belong to the same battle (2020).

But Slavoj Žižek rightly warns that we should resist seeking any deeper meaning in the COVID-19 crisis (2020: 14). Although we might find such meaning reassuring because it means that somehow our existence matters, we should not forget that we are merely one species, on one planet, with no particular significance (2020: 14). We have, though, a responsibility to read the stories of the crisis, to engage with its plot points, its genres, characters, settings and conflicts. This special curated issue was put together in haste but also with deep care and thought to begin mapping out those plot points. We wanted to capture this moment in time, document the year 2020, reflect on its ups and downs. This is why we opted to publish self-reflective essays as well as poems and short stories. We want to read and share lived experiences, get a sense of what the pandemic has meant across diverse national and transnational contexts, underline the affective rhythm of the virus on our mobility and sense of time, as well as deconstruct our privileges and restrictions that impact on each of us in different ways. In the coming months and years, cultural theorists and social scientists will investigate the pandemic from all angles. Peer-reviewed research will unpack the injustices, contradictions and ethics of lockdown. But for now PORTAL offers a selection of non-peer reviewed articles and cultural works that are often challenging, at times provocative, but always emotionally engaging. This underscores the desire, in a time of confusion and incertitude, to both own and share our stories and our personal and emotional strategies and responses.

The first section of the special issues includes thirteen reflective essays. Kiran Grewal reflects on solidarity, resistance and power, addressing the politically disruptive and radical potential of the present crisis. Her essay conveys the point of view of a transnational scholar experiencing lockdown in London and reflects on experiences and trajectories that revolve around her research fieldsite in Sri Lanka. Pan Wang's essay exposes the inequalities made visible by the pandemic, analysing prejudices and biases toward women, the elderly and Asian ethnic minorities. Liliana Correa and Frederick Copperwaite reflect on being artists and creatives during the pandemic and on the transformation of sense of time and place that they observed over the last few months. They advocate for the radical potential of voicing stories to contest inequality and lack of care of the most vulnerable, in particular First Nations peoples. Cadigia Hassan and Gianluigi Mangiapane write about a grass-root initiative in Italy that aims to capture a snapshot of the crisis through an analysis of the objects of affection that populate and accompany everyday life in lockdown. The essay by Yuliya Grikun, Mária Kubincova, Sau Man Luk, Anastasia Petrova, David Rands, Elham Saberi and Kaitlyn Ugoretz 
presents a critical and emotional bridge between the life before and during the pandemic, documenting the path of a group of scholars that were together in Japan for a study seminar at the time of the first outbreak, and their subsequent individual experiences of returning to their home countries. Suborna Camellia \& Kazi Nazrul Fattah document the emotional, social, physical and economic impact of COVID-19 on migrants. They reflect on their own experience of migration from Bangladesh to Australia, discussing precarity, belonging and in-betweenness. Ioannis Gaitanidis reflects on the disruption of study abroad programs in a Japanese university and on how mobility can be re-thought and reconceptualized in the present transformed context. Noah Riseman reflects on his privilege as a tenured professor at an Australian university and how the pandemic exacerbated the inequalities between tenured and casual academics. Cristina BalmaTivola offers a participant observation of the experience of lockdown in Turin, and a reflection on how communities reacted to measures imposed by the Italian government. Hongwei Bao's essay, through an analysis of a video artwork by Berlin-based queer filmmaker Popo Fan, unravels the politics of identity in the current global pandemic, pinpointing the role of queer disidentification as an important critical intervention in the current political debate circulating around the pandemic. Kate Averis reflects on the ways in which lockdown exposed and exacerbated gendered violence in Colombia, also discussing the responses of feminists, journalists, academics, writers and artists. Mobo Gao reflects on Australia's Chinese Communities, analysing political polarization in relation to responses to the COVID-19 pandemic, as observed in the main narrative threads of two WeChat groups. Finally, Marcello Messina's essay conveys his experience as an Italian migrant in Brazil, reflecting on the intersections between the COVID-19 pandemic, necropolitics, citizenship, and settler colonial contexts.

The second section presents six cultural works. Jean Duruz's creative piece of non-fiction conveys the emotional economy of everyday experiences across the pandemic. Susana Chávez-Silverman Spanglish narrative addresses issues of family, belonging and shame in the context of returning home during the outbreak. CJ Vallis's visual creative non-fiction text juxtaposes life under lockdown in Sydney 2020 with the author's experience of curfew in Kashmir in the 1990s. Chad Hammond's poem enters one of the many fractures created by the COVID-19 pandemic and pinpoints the divisions that it exposes. Ilongo Fritz Ngale's verses offer a creative reinterpretation of impacts of COVID-19 on space, time, mind, consciousness, emotions, thinking, and behaviour. Finally, Peter Ross's verse illuminates issues of inequality, exploitation, and class relations in the pandemic context.

The COVID-19 crisis is a story with no real end or beginning, no clear delineated chapters that can signpost to the reader where its narrative arc is heading. But inside this special issue of PORTAL you will find some fragments of the story from diverse locations in the world. Each essay, reflection or cultural work is a word, a sentence, a page, of the overall story. We invite you to read these fragments and join us on a journey to slowly piece together the story of a virus called COVID-19.

\section{References}

ABC Q\&A 2020, 'The Age of Loneliness,'14 September. Online, available: https://www.abc.net.au/ qanda/2020-14-09/12644106 [Accessed 10 November 2020].

Agamben, A. 2020a, 'The Invention of an Epidemic,' European Journal of Psychoanalysis. Online, available: http://www. journal-psychoanalysis.eu/coronavirus-and-philosophers/ [Accessed 10 November 2020].

2020b, ‘Giorgio Agamben: “Clarifications,” An und für sich, March 17, trans. A. Kotsko. Online, available: https://itself.blog/20/03/17/giorgio-agamben-clarifications/ [Accessed 10 November 2020].

Frankel, J. 2020, 'Covid-19 and the Climate Crisis are Part of the Same Battle,' Guardian, 2 October. Online, available: https://www.theguardian.com/business/2020/oct/02/covid-19-and-the-climate-crisis-are-part-of-the-same-battle [Accessed 9 December 2020]. 
Horowitz, J. 2020, 'Italy's Health Care System Groans Under Coronavirus - a Warning to the World,' New York Times, March 17. Online, available: https:/www.nytimes.com/2020/03/12/world/europe/12italy-coronavirus-health-care.html [Accessed 9 December 2020].

Latour, B. 2020, 'Is this a Dress Rehearsal?', Critical Inquiry, March 26. Online, available: https://critinq.wordpress. com/2020/03/26/is-this-a-dress-rehearsal/ [Accessed 10 November 2020].

SBS News, 'Health Dictatorship': Tony Abbott Rails against Victoria’s Coronavirus Response,'2 September. Online, available: https://www.sbs.com.au/news/health-dictatorship-tony-abbott-rails-against-victoria-s-coronavirus-response [Accessed 9 December 2020].

Villareal, L. P. 2008, 'Are Viruses Alive?’ Scientific American, August 8. Online, available:

https://www.scientificamerican.com/article/are-viruses-alive-2004/ [Accessed 9 December 2020].

Zhou, N. 2020, 'Almost 10\% of Australian University Jobs Slashed during Covid, with Casuals Hit Hardest,' Guardian, 7 October. Online, available: https://www.theguardian.com/australia-news/2020/oct/07/almost-10-of-australianuniversity-jobs-slashed-during-covid-with-casuals-hit-hardest [Accessed 9 December 2020].

Žižek, S. 2020, Pandemic!: COVID-19 Shakes the World, Polity, New York. https://doi.org/10.2307/j.ctv16t6n4q 